\title{
STUDY ON PATHOGENICITY OF COLLETOTRICHUM GLOEOSPORIOIDES ON COFFEE IN NORTH OF VIETNAM
}

\author{
THANH HA NGUYEN, THI NGAT HOANG, \\ THU HA NGUYEN THI, XUAN HOI PHAM
}

\author{
Institute of Agricultural Genetics
}

\begin{abstract}
Coffee is an important crop in Vietnam and it has recently brought a lot of benefit for the country through export. After coffee leaf rust, anthracnose is the second destructive disease for coffee production and is caused primarily by Colletotrichum gloeosporioides. In order to investigate the pathogenicity of $C$. gloeosporioides on coffee in the North of Vietnam, we carried out isolation of $C$. gloeosporioides species from different coffee plantations and found that $C$. gloeosporioides presents in different parts of coffee including leaf, twig, ripe berry and green berry. The pathogenicity of a total of twenty eight $C$. gloeosporioides isolates was tested on green berry in laboratory. Interestingly, two most pathogenic isolates were originated from green berry. In detail, the rate of green berry infection by C. gloeosporioides isolates varied from $4.44 \%$ to $76.67 \%$ and the variation of infection rate was also observed clearly among $C$. gloeosporioides isolates originating from leaf $(14.40 \%$ to $45.56 \%)$, twig ( $4.44 \%$ to $58.89 \%)$, ripe berry $(22.20 \%$ to $61.10 \%)$ and green berry $(24.40 \%$ to $76.67 \%)$. Three selected pathogenic isolates representing for $C$. gloeosporioides isolates originated from twig, ripe berry and green berry were further tested for pathogenicity on hypocotyl seedling in greenhouse. The rate of hypocotyl seedling infection by $C$. gloeosporioides isolates originated from twig, green berry and ripe berry is $48.89 \%, 37.78$ and $23.33 \%$ respectively. Our data suggests that pathogenicity of C. gloeosporioides is variable and specific among isolates, parts of coffee.
\end{abstract}

Key words: Colletotrichum gloeosporioides, pathogenicity, coffee anthracnose disease.

Colletotrichum gloeosporioides is the most predominant Colletotrichum pathogen, causes anthracnose disease in more than 197 species of plants including crops, weeds, and trees. This fungal pathogen causes serious disease on mango [10], avocado [5], citrus and apple [4], pasture legume... Especially, C. gloeosporioides is post-harvest and pre-harvest pathogen on avocado, mango and citrus. C. gloeosporioides is highly variable pathogen and considered as a group species [8]. However, there are few reports of damage caused by this pathogen. On coffee, there are three colletotrichum species cause anthracnose disease including $C$. kahawae, C. gloeosporioides and C. acutatum [6]. C. kahawae has so far only been found in Africa where it can cause yield losses up to $80 \%$ and can infect all of stages of crop from flowering to ripe berries. C. gloeosporioides is considered as a weakly pathogen compare to $C$. kahawae. However, C. gloeosporioides and $C$. acutatum were recently reported to cause anthracnose disease on Arabica coffee in New Guinea, only attacks to ripe berries and can causes yield losses up to $40 \%$ [6]. Some reports showed that $C$. gloeosporioides is secondary parasite following $C$. kahawae and is capable of overwhelming $C$. kahawae. This activity may enhance the CBD infection process under field conditions. In the field, from CBD infected berries, some isolates of $C$. gloeosporioides were isolated and determined as saprophytic [2].

In Vietnam, anthracnose disease observes at all coffee plantations and in differences part of coffee including leaf, Twig, ripe berry and green berry. The disease usually appears in the beginning of the rainy season (May) and causes damage in September during berry development and ripening. During recent years, it has mostly been observed on the Arabica cultivar which is now commonly grown in Vietnam. The yield losses caused by this disease ranged between 
$15-60 \%$ and varied among geographical zones. Among Colletotrichum species, $C$. gloeosporioides was the most commonly found from all anthracnose disease samples collecting difference zones $(7,9)$. In previous study, we have reported that $C$. gloeosporioides has been isolating from coffee anthracnose disease expressed diversity of morphology character [7]. In this study, we present virulence of two collection of $C$. gloeosporioides isolates from Nghe An and Ba Vi coffee plantations.

\section{MATERIALS AND METHODS}

\section{Fungal isolates}

Anthracnose disease samples from leaf, Twig, ripe berry and green berry were collected from Nghe An and $\mathrm{Ba} \mathrm{Vi}$ coffee plantations. Isolation of $C$. gloeosproides isolates were made from leaf, twig, ripe berry and green berry and identification was based on morphology and molecular characteristic (8).

\section{Preparation of fungus conidia suspension for inoculation}

A total of 28 C. gloeosproides isolates originated from Nghe $\mathrm{An}$ and $\mathrm{Ba} \mathrm{Vi}$ coffee plantations (table 1) and CBD56 isolate (C. kahawae) for positive control supported by CBS centre (Holland) were used for inoculation. Conidia suspensions were made from 7- to 10day-old PDA cultures grown at $25^{\circ} \mathrm{C}$ under $12 \mathrm{~h}$ fluorescent light and adjusted to $1 \times 10^{6}$ conidia/ml in sterile dionized water.

Material for inoculation: Green coffee berries, healthy twigs with coffee berry, coffee seedling were harvested from Nghe An and $\mathrm{Ba}$ Vi. These materials did not express any disease symptom and were considered as sanitary material.

Pathogenicity test: Coffee berries were washed with running water, surface-sterilized in alcohol $70 \%$ for 7 minutes, than rinsed by sterilize water three times. Berries were dispensed into plastic boxes with sterilize sand or humidity tissue (10 berries per box). One hundred microlites of inoculums was dropped on each fruit surface wounded slightly with sterilized pins. For the control, berries was infected by sterilize water. Tray was covered with white nylon for keep optimal humidity, put in the chamber with $12 \mathrm{~h}$ fluorescent light. The test was conducted with 3 boxes, repeat three times for each isolate.

Health twigs with coffee berries, twigs were also sterilized in running water and plunge three twigs into each sterilize water in flask. Berries in twigs were made wounding by syringe needle, sprayed conidia suspension every day in a week and covered with white nylon. Control was made as the same except using distilled water as inoculums.

Arabica coffee seedling was cultivated on sterilized sand in plastic tray $(30$ coffee seedlings per tray). Using needle wound on stem of 8 week-old coffee seedling. The cotton was dipped in the conidia suspension of $C$. gloeosporioides and wrapped strips of the cotton around the seedling. Covering the inoculation point by parafilm. Tray were covered by white nylon for blocking the lost of humidity and cross inoculation. After $24 \mathrm{~h}$ of incubation, drop $1 \mathrm{ml}$ of conidia suspension on cotton again. Watering every day. Each isolate was infected on three trays.

\section{RESULTS AND DISCUSSION}

\section{Isolation of $\boldsymbol{C}$. gloeosporioides isolates}

We conducted the survey and sample collection at coffee farms belonging Arabica Coffee Research Centre - Ba Vi and Coffee and Rubber Company - Nghe An. The anthracnose disease samples were collected and keep in newspaper at $4^{0} \mathrm{C}$ until isolation. From 19 and 37 anthracnose disease samples origination from green and ripe berry, leaf and twig from Nghe $\mathrm{An}$ and $\mathrm{Ba} \mathrm{Vi}$ (fig. 1), we isolated and identified 8 and 20 C. gloeosporioides isolates, respectively. In a total of $28 \mathrm{C}$. gloeosproides isolates; $6,12.5$ and 5 isolates originated from leaf, twig, green berry and ripe berry respectively (table 1). Because sample collection period at Nghe An is not fruiting time, so disease samples only were leaf and twig. These C. gloeosproides isolates were cultured on slant agar in the tube and keep at $4^{0} \mathrm{C}$ for conservation. 




a



b



c



d

Fig. 1. Anthracnose symptom on coffee

a. on ripe berries; b. on green berries; c. on twig; d. on leaf.

Table 1

Source of isolate of $C$. gloeosporioides from coffee at Nghe An and Ba Vi and percentage of infected berry with $C$. gloeosporioides after 6 days of inoculation

\begin{tabular}{|l|l|l|l|c|}
\hline $\mathbf{N}^{\mathbf{0}}$ & \multicolumn{1}{|c|}{ Isolate } & Host tissue & \multicolumn{1}{|c|}{$\begin{array}{c}\text { Geographical location of } \\
\text { isolates }\end{array}$} & $\begin{array}{c}\text { Percentage of infected } \\
\text { berries (\%) }\end{array}$ \\
\hline 1 & TH1.8(L)11 & Leaf & Nghe An & $45.56 \pm 0.98$ \\
\hline 2 & TH1.6(L)11 & Leaf & Nghe An & $35.56 \pm 1.73$ \\
\hline 3 & TH1.15(L)4 & Leaf & Nghe An & $42.22 \pm 1.23$ \\
\hline 4 & TH1.4(T)15 & Twig & Nghe An & $12.22 \pm 0.49$ \\
\hline 5 & TH1.14(T)19 & Twig & Nghe An & $57.78 \pm 1.97$ \\
\hline 6 & TH1.17(L)3 & Leaf & Nghe An & $41.1 \pm 2.47$ \\
\hline 7 & TH1.8(L)17 & Leaf & Nghe An & $27.78 \pm 1.97$ \\
\hline 8 & TH1.18(L)2 & Leaf & Nghe An & $14.4 \pm 1.97$ \\
\hline 9 & BVQ4R5 & Ripe berry & Ba Vi & $38.89 \pm 1.73$ \\
\hline 10 & BVQ2G & Green berry & Ba Vi & $74.4 \pm 2.69$ \\
\hline 11 & BV1G & Green berry & Ba Vi & $35.56 \pm 1.73$ \\
\hline 12 & BVT22 & Twig & Ba Vi & $58.89 \pm 3.2$ \\
\hline 13 & BVQ6G4 & Green berry & Ba Vi & $76.67 \pm 2.95$ \\
\hline 14 & BVT16 & Twig & Ba Vi & $42.2 \pm 3.2$ \\
\hline 15 & BVQ4R7 & Ripe berry & Ba Vi & $55.6 \pm 1.73$ \\
\hline 16 & BVT7 & Twig & Ba Vi & $14.4 \pm 1.23$ \\
\hline 17 & BVT10 & Twig & Ba Vi & $15.56 \pm 1.97$ \\
\hline 18 & BVT14 & Twig & Ba Vi & $14.4 \pm 0.98$ \\
\hline 19 & BVT19 & Twig & Ba Vi & $51.1 \pm 3.2$ \\
\hline 20 & BVT1 & Twig & Ba Vi & $33.3 \pm 1.48$ \\
\hline 21 & BVT20 & Twig & Ba Vi & $12.2 \pm 1.97$ \\
\hline 22 & BVT4 & Twig & Ba Vi & $16.67 \pm 1.48$ \\
\hline 23 & BVT11 & Twig & Ba Vi & $4.44 \pm 1.23$ \\
\hline 24 & BVQ6R1 & Ripe berry & Ba Vi & $22.2 \pm 1.23$ \\
\hline 25 & BVQ10R7 & Ripe berry & Ba Vi & $61.1 \pm 1.97$ \\
\hline 26 & BV2G & Green berry & Ba Vi & $37.8 \pm 2.7$ \\
\hline 27 & BVQ5G8 & Green berry & Ba Vi & $24.4 \pm 1.23$ \\
\hline 28 & BVQ12R4 & Ripe berry & Ba Vi & $55.6 \pm 1.73$ \\
\hline 29 & Control & & & 0 \\
\hline & & & \\
\hline
\end{tabular}

\section{Pathogenicity test}

Pathogenicity test on green berry showed that all 28 Colletotrichum isolates attacked and produced typical symptoms of anthracnose disease on inoculated green berries. Therefore, these isolates were considered to be pathogenic 
to coffee green berries. However, the rate of green berry infection by among $C$. gloeosporioides isolates was varied from $4.44 \%$ to $76.67 \%$ and the variation of infection rate was also observed clearly among gloeosporioides isolates originated from leaf ( $14.40 \%$ to $45.56 \%)$, twig $(4.44 \%$ to $58.89 \%)$, ripe berry $(22.20 \%$ to $61.10 \%)$ and green berry (24.40\% to $76.67 \%$ ). Of 12 C. gloeosporioides isolates from twig, 3 have infection rate more than $50 \%$. Of 5 C. gloeosporioides isolates from ripe berry, 3 have infection rate more than $50 \%$. Especially, of 5 C. gloeosporioides isolates from green berry, 2 have infection rate more than $70 \%$ (table 1). Analysis data reveal that $C$. gloeosporioides isolates from green berry have highest pathogenicity, then ripe berry, twig and leaf (fig. 2).



Fig. 2. Infection level on green berry of $C$. gloeosporioides isolates

The symptom on infected green berries appeared as typical anthracnose symptom on the field. The symptom begins with brown spot, than spread and become black. The lesions are wet, sunken, and some berries appear orange conidia mass (fig. 3).



a



b



c



d



e



f

Fig. 3. Anthracnose symptom on coffee berry after 6 days of inoculation a. Control; b. BVT22; c. TH1.14 (T) 19; d. TH1.8 (L) 11; e and f. BVQ2X 




b



Fig. 4. Conidia character of $C$. gloeosporioides re-isolated from green berries



a



b



c

Fig. 5. Colony morphology of $C$. gloeosporioides isolates using for pathogenicity test on coffee seedling. a. BVQ12R4; b. BVQ2G; c. TH1.14(T)19



a



b



$\mathrm{c}$

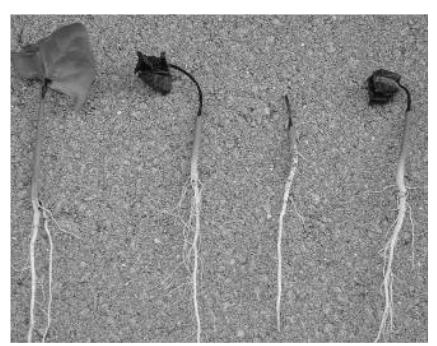

d

Fig. 6. Pathogenicity test on coffee seedling with TH1.14(T)19

a. after infection 7 days; $b$ and c. after 15 days; d. coffee seedling infected with CBD56

In order to confirm the infection of C. gloeosporioides on green berries, we reisolated fungal from infected green berries that have typical anthracnose symptom based on morphology character of conidia. The result shows that all of $C$. gloeosporioides isolates have been recovered from these infected green berries (fig. 4).

From the result of pathogenicity test on green berry, we screened three selected pathogenic isolates named TH1.14(T)19, BVQ2G, BVQ12R4, representing for C. gloeosporioides isolates originated from twig, ripe berry and green berry respectively for pathogenicity test on the healthy twigs with coffee berry and coffee seedling (fig. 5). These isolates had severely pathogenic on berries $(57.8 \%, 74.4 \%$ and $55.6 \%$, respectively).

We first did Pathogenicity test of C. gloeosporioides isolates on the healthy twigs with coffee berry. After 7 days, the disease symptom was not appeared clearly. The berries on all of twigs become yellow and fall out; this is also observed with control twigs. It is possible that coffee berries on twig have good vitality to overcome infection of pathogen (data is not shown).

On the coffee seedling, $C$. gloeosporioides showed weak virulence as compared to green berries. Infected seedling appeared slight 
anthracnose symptom, but the infection did not affect significantly its growth, as a result, it was able to grow to mature coffee. In contrast, upper part from wounded stem of infected seedling by CBD isolate was severely infected and consequently, a lot of seedling was dead (fig. 6).

Table 2

Percentage of coffee seedling appearing anthracnose symptom

\begin{tabular}{|l|c|c|c|c|}
\hline \multirow{2}{*}{\multicolumn{1}{|c|}{ Item }} & \multicolumn{4}{c|}{ Isolate } \\
\cline { 2 - 5 } & CBD56 & TH1.14(T)19 & BVQ2G & BVQ12R4 \\
\hline $\begin{array}{l}\text { Percentage of seedling with } \\
\text { symptom (\%) }\end{array}$ & $78.89 \pm 1.97$ & $48.89 \pm 1.97$ & $37.78 \pm 1.97$ & $23.33 \pm 2.22$ \\
\hline Level of virulence & +++ & ++ & + & + \\
\hline
\end{tabular}

Note: $(+++)$. Very strong virulence; $(++)$. Medium virulence; $(+)$. Weakly virulence.

It has been reported that $C$. gloeosporioides from coffee is a weakly pathogen, only attacks to ripe berry in the field condition. It has not infected on detached green coffee berries, whiles penetration of $C$. kahawae occurred. However, C. gloeosporioides is capable of penetration when green berries were subjected to previous heat shock of $55^{\circ} \mathrm{C}$ for $30 \mathrm{~s}$. In addition, inoculation of $C$. gloeosporioides on ripe berries was occurred, but only was limited to the inoculated area $[1,2,6]$. In our research, all $C$. gloeosporioides isolates from leaf, twig, ripe berry and green berry are pathogenic to detached green coffee berries coffee. Especially, two $C$. gloeosporioides from green berry are very pathogenic with infection rate very high (76.67\%), suggesting that a potential threat of C. gloeosporioides isolates for Vietnam coffee production has been developed.

It has also reported that $C$. gloeosporioides is able to infected on coffee hypocotyl seedling (3). C. gloeosporioides isolates from difference coffee plantations of Vietnam has possibility of infection and induced the severely anthracnose symptom on hypocotyl seedling. However, their virulence on hypocotyl seedling is not severity.

\section{REFERENCES}

1. Chen Z., Ribeiro A., Silva M. C., Santos P., Guerraguimaraes L., Gouveia M., Fernandez D. and Rodrigues C. J., 2003:
Physiological and Molecular plant, 63(4): 181-190.

2. Chen Z., Liang J. and Rodrigues C. J. Jr., 2005: Biotechnology Letters, 27: 679-682.

3. Eshetu D. and J. M. Waller., 2003: Crop protection, 22(3): 561-565.

4. Eugenia G. and Turner B. S., 2004: Plant disease, 88(12): 1335-1340.

5. Gina M. S. and L. Korsten, 2003: Can. J. Bot., 81: 877-885.

6. Kenny M. K., Galea V. J., Scott P. T. and Price T. V., 2006: Pest and disease. Report. No. 62.

7. Nguyen T. H., Hoang T. N., Nguyen T. H., Le T. A. H. and Pham X. H., 2008: Journal of Vietnamese Agricultural Science and Technology, 3(8): 52-57.

8. Peter R. M., Sreenivasaprasad S. and Averil E. B., 1992: FEMS Microbiology letters, 98: 137-144.

9. Tran K. L., Vu T. T. N. and Ngo T. X. T., 1998: Monthly Journal of Sciences, Technology and Economic management, 6: 253-255.

10. Son Q. D., Julapark Ch., Patchara P. and Somsiri S., 2003: Australasian Plant Pathology, 32, 533-538. 


\title{
NGHIÊN CƯUU ĐÔC TÍNH NẤM COLLETOTRICHUM GLOEOSPORIOIDES GÂY BỆNH TRÊN CÀ PHÊ Ở MIỀN BÁC VIỆT NAM
}

\author{
NGUYỄN THANH HÀ, HOÀNG THI NGÁT, \\ NGUYỄN THI THU HÀ, PHẠM XUÂN HỘI
}

\section{TÓM TÁT}

Cà phê là cây trồng quan trọng ở Việt Nam, gần đây mang lại rất nhiều lợi nhuận cho quốc gia thông qua việc xuất khẩu. Sau bệnh dỉ sắt, bệnh thán thư cà phê gây ra bởi nấm $C$. gloeosporioides có mức độ nguy hiểm thứ hai. Để nghiên cứu độc tính của $C$. gloeosporioides trên cà phê ở các tỉnh phía Bắc Việt Nam, chúng tôi tiến hành phân lập các chủng $C$. gloeosporioides ở các vùng trồng cà phê và phát hiện nấm $C$. gloeosporioides gây hại trên các bộ phận khác nhau của cây bao gồm lá, cành, quả chín và quả xanh. Độc tính của 28 chủng nấm $\dot{C}$. gloeosporioides được kiểm tra trên quả cà phê xanh ở điều kiện phòng thí nghiệm. Điều thú vị là hai chủng có độc tính cao nhất có nguồn gốc từ quả cà phê xanh. Cu thể, tỉ lệ lây nhiễm quả xanh của các chủng C. gloeosporioides dao động từ 4,44\% đến $76,67 \%$ và độ giao động về tỉ lệ lây nhiễm cũng được quan sát rất rõ giữa các chủng nấm $C$. gloeosporioides có nguồn gốc từ lá $(14,40 \%$ to $45,56 \%)$, cành $(4,44 \%$ to $58,89 \%)$, quả chín $(22,20 \%$ to $61,10 \%)$ và quả xanh $(24,40 \%$ to $76,67 \%)$. Ba chủng độc tính trên quả xanh đại diện cho các chủng nấm $C$. gloeosporioides có nguồn gốc từ cành, quả chín và quả xanh được tiếp tục nghiên cứu độc tính trên cây con ở giai đoạn vườn ươm trong điều kiện nhà kính. Tỉ lệ lây nhiễm cây con của các chủng nấm C. gloeosporioides có nguồn gốc từ cành, quả xanh và quả chín tương ứng là $48,89 \%, 37,78 \%$ và $23,33 \%$. Kết quả nghiên cứu của chúng tôi chứng tỏ độc tính của các chủng $C$. gloeosporioides thay đổi và đặc hiệu giữa các chủng nấm và bộ phận của cây.

Ngày nhận bài: 12-1-2010 